\title{
Translator's Introduction
}

Shen Yanbing (1896-1981), better known by his pen name, Mao Dun, was born in Tongxiang county, Zhejiang, during the final years of China's last imperial regime. Mao Dun received a modern education, first at a middle school in Hangzhou and later as a student of literature at National Beijing University. In 1916, after three years at the university, financial difficulties forced Mao Dun to cut his academic career short and take a job as a proofreader at the Commercial Press (Shangwu Yinshuguan) in Shanghai.

Because he was born only two years before the 1898 reforms and China's abortive initial attempt at constitutional government, Mao Dun's early life coincided with the flowering of China's first cultural revolution and the beginning stage of the political revolution that would end in the founding of the People's Republic of China. The year he left school saw the death of Yuan Shikai, first president of the Republic of China, and the outbreak of the civil war among competing military governors known as the Warlord Era. Internal disorder, despair at the pressures exerted on China by the Western powers and Japan, and an increasing awareness of China's economic backwardness also gave rise to an intensified search by educated Chinese for the key to China's national salvation. The most influential group of intellectuals who addressed these problems were those dedicated to the complete overthrow of traditional values and the development of a "new culture" and "new thought."

In 1915, New Youth (Xinqingnian), one of the leading journals that provided a forum for the cultural iconoclasm and intellectual experimentation of the period, was founded in Beijing by Chen 
Duxiu. Soon afterward, in 1919, Chinese outrage at the clause in the Treaty of Versailles that transferred Germany's Chinese concessions to Japan led to rioting in cities throughout China. The May Fourth Movement, named for the day on which the first of these anti-imperialist demonstrations took place, saw the joining together of patriotic fervor with the intellectual rebellion of China's youth and provided the inspiration for many of China's modern writers and poets, including Mao Dun.

Shanghai, where Mao Dun spent much of the 1920s, was a center for both political and cultural activism. Promoted to a position as an editor and a translator at Commercial Press, Mao Dun found ample opportunity to immerse himself in the works of writers such as Dickens, Chekhov, and Tolstoy. He was also one of the first Chinese literary critics to recognize the value of less well-known writers from both Western and Eastern Europe. In 1920 he founded the Literary Association, and in 1921 he helped reorganize the journal Short Story Monthly (Xiaoshuo yuebao), acting as its editor until he stepped down in 1923 .

At the same time that Mao Dun was developing his interests in a modern vernacular prose, his political and social concerns were drawing him to the growing body of socialist literature becoming available in China in the late 1910s. Political pressure in Beijing drove increasing numbers of radicals to Shanghai during the last years of the decade, and it is likely that Mao Dun joined one of the Marxist study groups founded in the city in 1920 . Mao Dun's political activities appear to have taken precedence over intellectual pursuits during the early 1920s. He joined the Chinese Communist Party in August 1921, one month after its founding in Shanghai. Mao Dun participated in the party's efforts to organize labor during these years, both as a strike organizer and as a member of the worker's education movement. In 1923 and 1924 he taught at Shanghai University, a center for the training of party cadre, and in 1925 he played an active part in the anti-imperialist demonstration known as the May Thirtieth Incident.

For both communists and members of the Nationalist Party (Guomindang), the political goal of the mid-1920s was a joint northern expedition to overthrow China's numerous independent warlords and restore the beleaguered country to unified republican rule. In 1926 Mao Dun left for Guangzhou to join in this effort 
as a propagandist for the Political Department of the United Front government. And when the expedition's armies captured the strategic Wuhan cities in central China, Mao Dun remained in Hankou as editor of the newspaper National Daily (Minguo ribao). When the Nationalist government turned on the Communist Party in the spring of 1927 , open political activity became more difficult, and Mao Dun left Shanghai for Japan in July 1928 and did not return until April 1930.

These years of political activism were a period of relatively sparse literary output for Mao Dun and even sparser results for the political movement he strove to serve. Nevertheless, out of the despair and disillusion these years spawned came the most compelling of Mao Dun's creative works. By 1928 he had completed his first fictional effort, a trilogy of three short novels-Disillusion (Huanmie), Vacillation (Dongyao), and Pursuit (Zhuiqui). Later published under the collective title Eclipse (Shi), they describe in vivid and depressing detail the events surrounding the northern expedition he had just lived through. These three novels served to establish Mao Dun's reputation as one of the leading writers of Chinese vernacular fiction and were soon followed by Rainbow (Hong), the first three chapters of which first appeared as a serial in Short Story in 1929. Mao Dun's best known works, Midnight (Ziye, 1933) and the so-called rural trilogy of short stories, "Spring Silkworms" ("Chuncan"), "Autumn Harvest" ("Quishou"), and "Winter Ruin" ("Candong"), continued his exploration of moral and economic bankruptcy in China in the midst of national crisis.

During World War II Mao Dun continued to write novels, short stories, and plays, including Corrosion (Fushi, 1.941) and Maple Leaves as Red as Flowers of the Second Month (Shuangye hongsi eryuehua, 1943). But following the founding of the People's Republic of China, he was named minister of culture, and his creative work was largely replaced by his work as a bureaucrat and a leading cultural cadre in the new regime.

Mao Dun's mastery of descriptive detail and his objective representation of historical events have earned him praise as one of China's first "naturalist" or "realist" writers. In Rainbow we see a melding of several aspects of Mao Dun's creative genius. First, Rainbow takes its place with Eclipse and Midnight as a historical documentary of China's revolutionary process. The heroine, Mei, 
like hundreds of thousands of Chinese youths in the early years of the century, undertakes to travel the road from the limitations of traditional family life to the discovery of new, "modern" values of individualism, sexual equality, and political responsibility. These values were articulated in innumerable articles and works of fiction by the proponents of the New Thought Tide that flooded China in the wake of the May Fourth Movement. For Mei, the journey ends in political activism, as it did for Mao Dun himself. Indeed, the events of the last chapter are drawn almost entirely from the author's own experiences in the demonstrations that followed the 1925 May Thirtieth Incident.

Nevertheless, Rainbow is foremost a psychological novel, and Mei's travels are as much mental as physical. Through Mei's interactions with others and through frequent use of interior monologue, Mao Dun explores with impressive honesty the competing emotions and often selfish ambitions that motivate his heroine and the people she meets. It is with equal honesty that he unmasks the hypocrisy of a "new thought tide" that presents young people with the imperative to smash the old morality but gives them neither the tools to do so nor a safe haven when they are through. For Mei, as for many young people during this turbulent period in Chinese history, it is a quest for personal liberation, not a commitment to well articulated political goals, that leads to participation in the revolutionary movements of the 1920s. In Rainbow, the struggle has just begun.

This translation of Rainbow is based on the 1941 Kaiming Shudian reprint of the original 1930 edition. It began as a form of recreation and a way to expand my vocabulary while enjoying the art of one of China's foremost modern novelists. As a translator I have tried to remain true to the original. At times this was not easy. As the "Postscript" indicates, Mao Dun wrote this novel in selfimposed exile, in a mood of despair at the Nationalist betrayal of the revolution whose beginnings we glimpse in Rainbow. The tension Mao Dun describes between "the cause" and the personal problems of the individual is reflected in the increasingly disjointed way in which Mei's relationships are depicted in the second half of the book. And Rainbow's intended place as the first book of a never-completed trilogy will undoubtedly leave some readers yearning to know what happens to Mei as she and the Chinese rev- 
olution achieve a new maturity at the novel's end. Inasmuch as Mei stands as a symbol for the youths, and particularly the young women of her day, I hope this will stimulate some readers to an exploration of the great variety of historical and literary works on modern China now available in English.

When the product of this exercise in translation ceased to be for my eyes only, a number of people kindly offered their advice and expertise. At the University of California Press I was fortunate to have the editorial advice of Betsey Scheiner, Marilyn Schwartz, and Jan Kristiansson. At Columbia, Shi Youshan, Tang Yiming, and Liang Heng each checked parts of the manuscript for accuracy of translation. Howard Goldblatt provided endless encouragement. He, David Wang, and the anonymous readers for the University of California Press checked the text against the original and provided valuable stylistic and editorial suggestions. To all these people I express my deepest gratitude.

Madeleine Zelin New York, May 1991 
This page intentionally left blank 